\title{
DISTRIBUTION AND ABUNDANCE OF MACROALGAE IN INTERTIDAL ZONE OF DRINI BEACH, GUNUNGKIDUL, DIY
}

\author{
Wiga Pratama, Shinta C. Dewi, Ihda Z.R. Sari, Anisa Hardiyati, \\ and Allan E. Wajong \\ Marine Study Club, Faculty of Biology, Universitas Gadjah Mada \\ wiga_pratama@yahoo.com
}

\begin{abstract}
Macroalgae is a macroscopic algae living in the intertidal zone. Based on the dominant pigment algae can be divided into 3 groups, there are Chlorophyta (green algae), Phaeophyta (brown algae), and Rhodophyta (red algae). Macroalgae have ecological and economic roles that are beneficial for humans. This research aims to study of distribution and abundance of macroalgae in the intertidal zone of Drini Beach, Gunungkidul, Yogyakarta. The study was conducted on June 8, 2013. Data were collected using plot method with $100 \mathrm{x}$ $100 \mathrm{~cm}^{2}$ quadratic plot at 17 sampling points. Measurement of physicochemical parameters in each sampling point including salinity, air temperature and water temperature. Data analysis was performed by calculating the percent cover of each type macroalgae. The results showed that macroalgae were found consist of 9 types of Rhodophyta, 7 types of Chlorophyta and 2 types of Phaeophyta. The highest abundance of macroalgae was Rhodophyta (50,76\%), followed by Chlorophyta $(43,37 \%)$ and the lowest one was Phaeophyta $(5,88 \%)$. The highest abundance of macroalgae species is Chaetomorpha crassa $(26,91 \%)$ and the lowest one is Gigartina sp. (0,02\%).
\end{abstract}

Keywords: Distribution, Abundance, Macroalgae, Intertidal

\section{INTRODUCTION}

Macroalgae or seaweed is a formed of algae that macroscopic size. As a benthic organisms, macroalgae grow on rocky and sandy substrates (Dawes, 1998). In general, macroalgae are distinguished based on similarity of form and color which is divided into three divisions: Chlorophyta (green algae), Phaeophyta (brown algae), and Rhodophyta (red algae) (Chan et al., 2006). Ecologically macroalgae play an important role as primary producers, can degrade heavy metals, potentially as a biomonitoring pollutants (Dawes, 1998), and shelter, nursery grounds and food sources for marine organisms (Prathep, 2005). Economically several types of macroalgae an industrial raw material carrageenan, agar-agar, cosmetic, pharmaceutical, food sources, organic fertilizers, and others (Dawes, 1998; Prathep, 2005).

Intertidal zone is an area of open beach which regularly exposed tidal wave, where the land meets the sea which is home to a variety of marine communities. One of the important components that play an important role in the growth and presence of macroalgae species is the substrate. Type of bottom substrate affects the types of benthic organisms that live on the surface. Not only that, the distribution and abundance of macroalgae communities in particular intertidal rocky shores are affected by various abiotic variables such as tidal regimes, wave action, nutrient levels, substrate stability, desiccation, and sedimentation (Dawes, 1998).

Drini Beach located in Gunungkidul, D.I. Yogyakarta. In the intertidal zone of the beach is a lot of macroalgae that grow as benthic organisms. This site has rocky substrate. Until now 
in the intertidal zone Drini Beach, still little information and research has studied the ecological aspects of macroalgae. These research aimed to study the distribution and abundance of macroalgae in intertidal zone of Drini Beach and influence factors of it. The results can provide information about the condition of Chlorophyta Drini beach today and is expected to be used as reference data for further research.

\section{MATERIALS AND METHODS}

The study conducted on June 8, 2013 during low tide when macroalgae were exposed in Drini Beach, Gunungkidul, DIY, Indonesia (Figure 1.). Sampling uses transect quadrat method ${ }^{1}$ with the square plot size of $100 \times 100 \mathrm{~cm}^{2}$ were divided into subplots $10 \times 10 \mathrm{~cm}^{2}$. In this work, the macroalgae populations were inventoried and quantified in 17 transects. Each plot measured percent cover macroalgae and physicochemical parameters including salinity, air temperature and water temperature. Macroalgae were collected and taken to the laboratory for identification to species various taxonomical keys and were also data calculated. Percent cover macroalgae species calculated using the following equation (Tuwo, 2011).

$$
P i=\frac{a i}{A}
$$

Description:

$\mathrm{Pi}=$ covered species $\mathrm{i}(\%)$

ai $=$ the total cover species $\mathrm{i}(\%)$

$\mathrm{A}=$ the total area covered macroalga (\%)

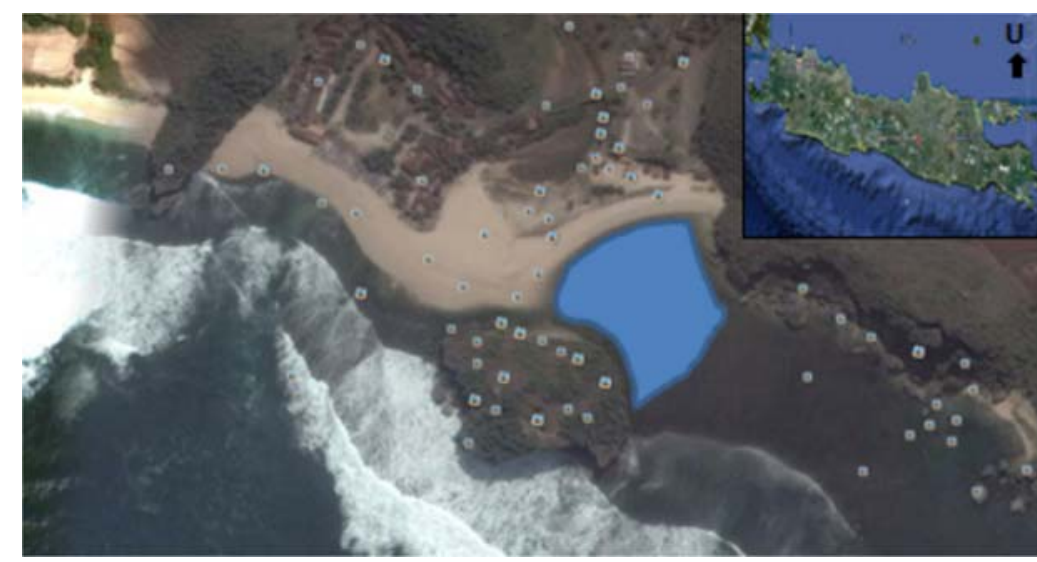

Figure 1. The study site, intertidal zone of Drini Beach, Gunungkidul

\section{RESULTS AND DISCUSSION}

The results showed that macroalgae were found consist of 9 types of Rhodophyta, 7 types of Chlorophyta and 2 types of Phaeophyta. Base on Figure 2. the highest abundance of macroalgae was Rhodophyta ( $50,76 \%)$, followed by Chlorophyta $(43,37 \%)$ and the lowest one was Phaeophyta $(5,88 \%)$. The majority of the macroalga species in the world are red algae (Rhodophyta) with more than 4000 described species. Otherwise, Phaeophyta showed the lowest species divesity because the majority are in temperate regions and only a few species are found in tropical regions (Lee, 1999). 


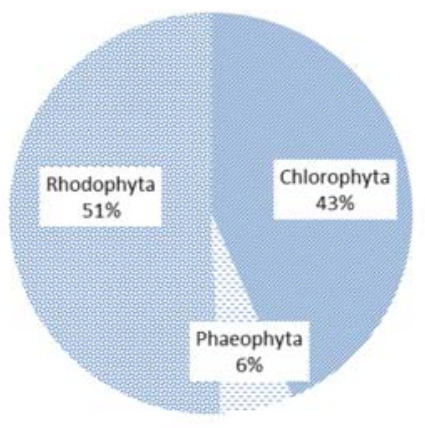

Figure 2. Percent cover of macroalgae in the intertidal zone of Drini Beach

Based on Figure 3. the highest abundance of macroalgae species is Chaetomorpha crassa (26,91\%), Glacilaria edulis (21,39\%), and Gelidiella acerosa (14,69). C. crassa had filamentous thalus that can withstand environmental stress. This species is also known to be able to live on saltwater or freshwater, has a high salinity tolerance and high reproductive capability (Heo et al., 2011). Glacilaria edulis and Gelidiella acerosa is economically important red algae. They ussualy found in protected area near islands having sandy or rocky bottom (Jayasankar \&Varghese, 2002). As shown in the study site, Drini Beach is protected by a small island which is also called the Island Drini. Then the lowest is Gigartina sp. $(0,01 \%)$ and $H$. crispa $(0,30 \%)$. Usual habitat of $H$. crispa in a deep water $(7-24 \mathrm{~m})$ (Dawes, 1998). This results suggest that in the intertidal zone of Drini Beach, the distribution and abundance of macroalgae are influenced by the substrates and exposure condition. Substrates are important components that play role in the growth and presence of macroalgae (Dawes, 1998).

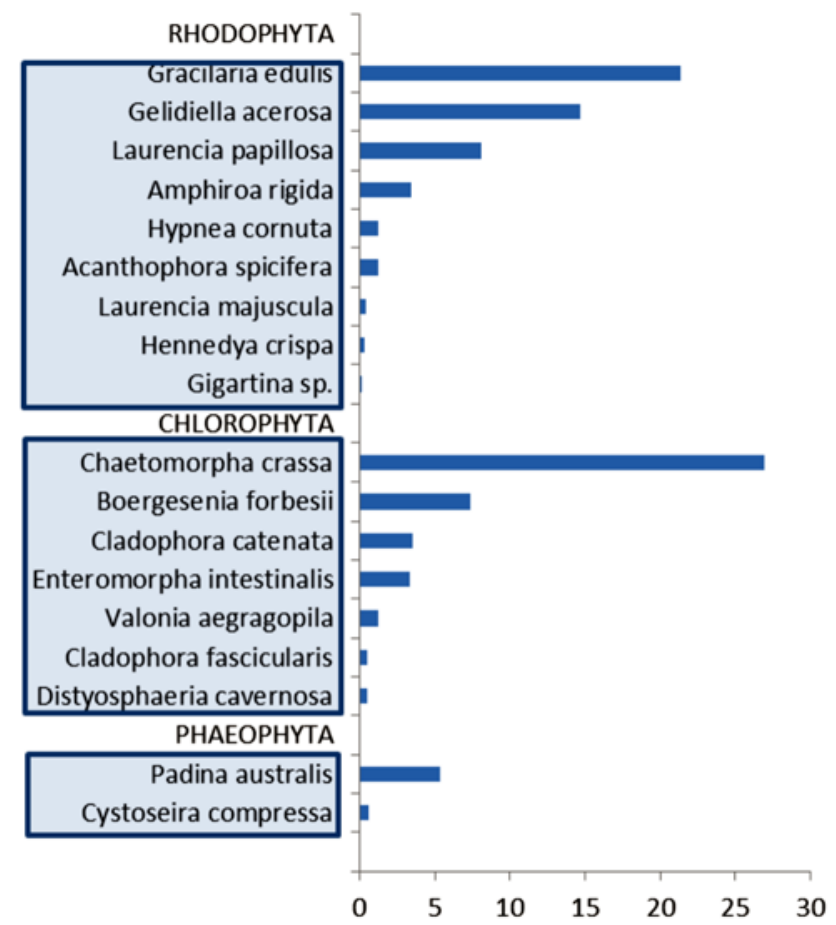

Figure 3. Percent cover of species in the intertidal zone of Drini Beach 


\section{ACKNOWLEDGMENT}

We are grateful to KSK Biogama for the support.

\section{REFERENCES}

Abraham, S.K. 2009. Metode dan analisa kuantitatif dalam bioekologi laut. Pusat Pembelajaran dan Pengembangan Pesisir dan Laut, Jakarta.

Chan, C.X., C.L. Ho and S.M. Phang. 2006. Trends in seaweed research. TRENDS in Plant Science, vol. 11:165-166.

Dawes, C.J. 1998. Marine botany, $2^{\text {nd }} e d$. John Wiley \& Sons, New York.

Heo, J.S., S.K. Park, H.L. Yoo, J.N. Song, B.Y. Kim and H.G. Choi. 2011. Macroalgal community structure in the rocky shores of Ongdo, Jusamdo, and Woejodo Island of the Yellow Sea, Korea. Fisheries and Aquatic Science, vol. 14:389-397.

Jayasankar, R., and S. Varghese. 2002. Cultivation of marine red algae Glacilaria edulis (Gigartinales, Rhodophyta) from spores. Indian Journal of Marine Sciences, vol. 31(1):75-77.

Lee, R. E. 1999. Phycology. Cambridge Uiversity Press, Cambridge.

Prathep, A. 2005. Spatial and temporal variations in diversity and percentage cover of macroalgae at Sirinart Marine National Park, Phuket Province, Thailand. Science Asia, vol. 31:225-233.

Tuwo A. 2011. Pengelolaan ekowisata pesisir dan laut: pendekatan ekologi, sosial-ekonomi, kelembagaan, dan sarana wilayah. Brilian Internasional, Surabaya. 